\title{
Ketahanan Entrepreneur Perempuan pada Masa Pandemi COVID-19
}

\author{
Paskanova Christi Gainau ${ }^{\mathrm{a}, *}$, \& Yuli Rawun ${ }^{\mathrm{b}}$ \\ a Universitas Pattimura, Ambon \\ ${ }^{b}$ STIE Eben Haezar, Manado
}

\begin{abstract}
The outbreak of COVID-19 has weakened the performance of micro businesses, especially micro scale women entrepreneurs. Entrepreneurs implement various measures to sustain their businesses through the pandemic. This study aims to examine the factors that influence the performance of micro businesses in the city of Manado, North Sulawesi Province. The study uses the sample of 30 micro businesses collected through questionnaires, observations, and interviews with women entrepreneurs with stratified random sampling technique. The collected data was then analyzed with SmartPLS 3.0 M3. The results found that trust and networks have significant influences on the performance of micro businesses during the crisis. The findings imply that businesses need to establish strong relationships with customers as a mean to building trust and networking to enable businesses to survive in the midst of a crisis. In addition, businesses should also improvise their products in times of crisis to maintain the cash flow.
\end{abstract}

Keywords: women entrepreneur; business performance; trust; smartPLS

\begin{abstract}
Abstrak
Pandemi COVID-19 telah menghambat produktivitas usaha di sektor mikro, tidak terkecuali para pelaku usaha perempuan. Penelitian ini bertujuan menganalisis faktor-faktor yang memengaruhi kinerja usaha sektor mikro di Kota Manado, Sulawesi Utara. Penelitian ini menggunakan sampel yang dipilih secara acak yang terdiri dari 30 pelaku usaha mikro perempuan. Data dianalisis menggunakan SmartPLS 3.0 M3, setelah melalui proses penyebaran kuesioner, observasi, dan wawancara. Hasil penelitian menemukan bahwa faktor kepercayaan (trust) dan jaringan (network) memiliki pengaruh signifikan terhadap kinerja usaha mikro di masa krisis. Kedua faktor ini sangat penting karena kepercayaan dan jaringan memberikan kemampuan bagi pelaku usaha untuk tetap bertahan di masa krisis. Selain itu, pelaku usaha juga sebaiknya melakukan improvisasi atas produknya di masa krisis untuk menjaga kelancaran arus kas.
\end{abstract}

Kata Kunci: entrepreneur perempuan; kinerja usaha; kepercayaan; smartPLS Kode Klasifikasi JEL: J16; M10; M31

${ }^{*}$ Alamat Korespondensi Penulis: Jl. Ir. M. Putuhena, Poka, Tlk. Ambon, Kota Ambon, Maluku. E-mail: paskanova.gainau@feb.unpatti.ac.id. 


\section{Pendahuluan}

Usaha mikro yang merupakan skala terkecil dalam UMKM diibaratkan sebagai raksasa yang tengah tidur. Alasannya, gerak usaha mikro telah menyerap ratusan ribu tenaga kerja perempuan di Indonesia (Wilantara \& Susilawasi, 2016). UMKM merupakan salah satu fondasi utama perekonomian negara karena memiliki kontribusi terbesar dalam mengembangkan potensi yang dimiliki oleh para pelaku ekonomi. Kinerja ini sedikit tergoncang ketika COVID-19 menjangkiti Indonesia.

Meningkatnya korban terjangkit ini turut berdampak pada melemahnya Indeks Harga Saham Gabungan (IHSG). IHSG merupakan salah satu indikator kesehatan perusahaan domestik sehingga melemahnya IHSG di masa pandemi menunjukkan bahwa perusahan-perusahaan domestik yang terdaftar di Bursa Efek Indonesia (BEI) tercatat mengalami penurunan kinerja, termasuk di dalamnya perusahaan bermodal besar yang merupakan tulang punggung ekonomi nasional (Grafik 1).

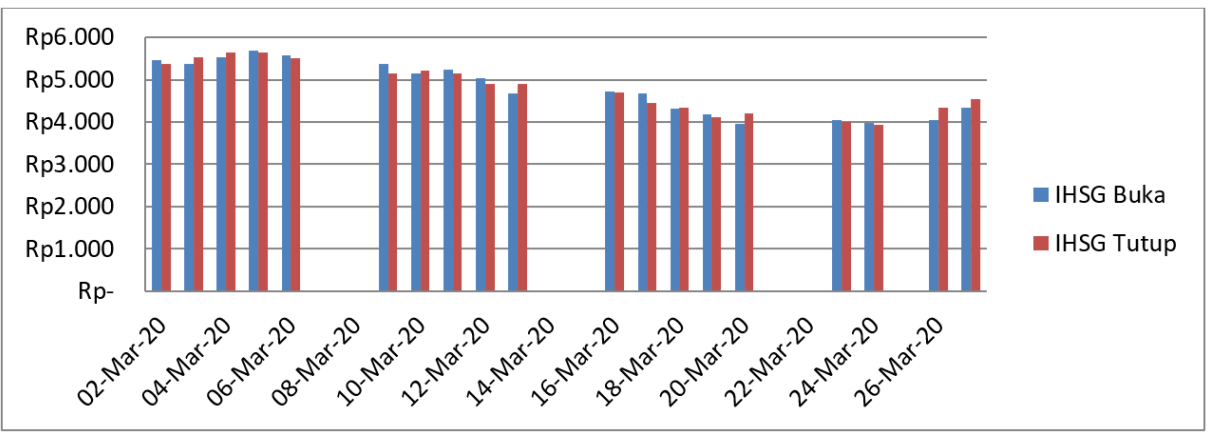

Grafik 1: Kinerja IHSG Maret 2020

Sumber: MNC Securities Daily Report (2020)

COVID-19 juga berdampak pada usaha kecil. Sulawesi Utara didominasi oleh UMK dan sampai tahun 2015 terdapat 640.000 tenaga kerja diserap di sektor ini dan Kota Manado menyumbang jumlah UMK terbanyak yaitu sebesar 60.961 usaha (Badan Pusat Statistik [BPS] Provinsi Sulawesi Utara, 2018).

Tabel 1: Data Tenaga Kerja Industri Mikro Sulawesi Utara

\begin{tabular}{lcc}
\hline \hline Industri & 2014 & 2015 \\
\hline Mikro & 61.792 & 71.833 \\
Kecil & 420 & 351 \\
\hline Sumber: & BPS Sulawesi & Utara (2016)
\end{tabular}

Sebagian besar pelaku usaha mikro ini adalah perempuan (BPS Provinsi Sulawesi Utara, 2018). Fenomena yang terjadi menunjukkan bahwa improvisasi 
yang dilakukan pelaku usaha di masa krisis adalah menjalin hubungan dengan konsumen melalui media sosial dan mengantarkan produk ke rumah konsumen. Kota Manado memiliki budaya Mapalus yang dikenal sebagai penangkal krisis ekonomi. Sistem budaya Mapalus bersifat gotong royong, dimana pihak yang kuat harus membantu yang lemah. Perempuan dipandang sebagai pihak yang kuat bertahan di masa krisis yang mampu melakukan improvisasi agar usahanya tetap berjalan. Rante (2010) menemukan bahwa faktor kebudayaan di tiap daerah atau suku secara signifikan berpengaruh positif terhadap kinerja usaha kecil. Pada umumnya, sebuah usaha dapat berkembang dengan dukungan modal fisik (uang, perlengkapan dan peralatan produksi) dan modal manusia (keterampilan), maka di masa krisis keberadaan dua jenis modal tersebut saja tidak cukup. Sistem ekonomi konvensional menunjukkan bahwa ada modal yang berpengaruh lebih kuat terhadap ketahanan sebuah usaha, yakni modal sosial. Selanjutnya, riset ini ingin mengkaji bagaimana peranan modal sosial dalam kehidupan usaha perempuan di masa pandemi COVID-19.

Modal sosial adalah sumber daya yang dapat digunakan untuk mencapai berbagai tujuan dan tertanam dalam jejaring sosial (Woodhouse, 2006). Grootaert \& Van Bastelaer (2002) mendefinisikan modal sosial sebagai institusi, relasi, sikap, dan nilai-nilai yang menjadi dasar bagi setiap orang dalam berinteraksi dan berkontribusi terhadap pembangunan ekonomi dan sosial. Stam et al. (2014) menemukan bahwa modal sosial berdampak positif terhadap kinerja usaha kecil. Interaksi sosial, kepercayaan, dan hubungan timbal-balik (resiprositas) berperan sebagai elemen penting untuk menghasilkan keuntungan bagi sebuah usaha (Grootaert \& Van Bastelaer, 2002).

Liao \& Welsch (2005) menemukan tiga bentuk modal sosial yang memengaruhi ruang lingkup kewirausahaan yaitu kognitif, relasional dan struktural. Kognitif berkaitan dengan pengetahuan pelaku usaha tentang pengelolaan usaha. Relasional berkaitan dengan kemampuan menjalin hubungan dengan lingkungan usaha. Struktural berkaitan dengan kemampuan pelaku usaha dalam mengatur struktur organisasi dan struktur keuangannya.

Hal ini menunjukkan bahwa modal sosial memiliki peran penting bagi kinerja sebuah usaha. Modal sosial merujuk pada aspek relasi yang kuat, kepercayaan dari lingkungan, dan kemampuan konseptual (Munizu, 2010; Steiner \& Wang, 2016; Sandra \& Purwanto, 2015; Schenkel et al., 2012). Selain itu, penelitian sebelumnya (Primadona \& Emrizal, 2017; Pierre, 2017; Schenkel et al., 2012; Singh et al., 1999; Thobias et al., 2013) juga menemukan bahwa modal sosial berdampak signifikan terhadap pertumbuhan usaha. Temuan Setyawan et al. (2019) dan Spekman \& Carraway (2006) juga menunjukkan bahwa elemen utama dalam relasi berbisnis adalah kepercayaan (trust). Secara spesifik, Davidsson \& Honig (2003) menemukan bahwa faktor kekeluargaan dan pertemanan akan berpengaruh positif terhadap jalannya usaha karena di dalamnya mengandung unsur kepercayaan yang kuat.

Kontribusi utama dari modal sosial adalah menunjukkan hubungan antara informasi dan aktivitas wirausaha berdasarkan kekuatan ikatan sosial, misalnya 
hubungan dengan kenalan. Jenis hubungan ini memiliki potensi untuk membuat usaha lebih berkembang karena terdapat unsur kepercayaan (trust) yang kuat dan resiprositas (reciprocity) antara pelaku usaha dengan lingkungannya. Selain itu juga akan mendorong tercapainya tujuan usaha karena tersedianya sumberdaya secara terus-menerus (Schenkel et al., 2012).

Investasi dalam hubungan sosial menciptakan goodwill bagi perusahaan dan masyarakat. Hal ini membantu mengadakan sumber daya bagi perusahaan. Berbagai studi telah mengeksplorasi peran modal sosial di berbagai tingkatan dan menemukan hasil bahwa modal sosial turut memengaruhi kinerja usaha (Florin et al., 2003). Reio \& Ghosh (2009) juga menyatakan bahwa kemampuan sosial berpengaruh terhadap kinerja usaha secara signifikan. Temuan-temuan sebelumnya ini cenderung terdapat di negara-negara maju.

Terdapat tiga hal yang dihasilkan dari menguatnya modal sosial, yakni munculnya motivasi untuk saling membantu (reciprocity), saling percaya (trust), dan kekompakan (cohesiveness). Kolaborasi dari ketiga hal tersebutmampu mendorong kinerja usaha.Tiga parameter modal sosial menurut Ridell dalam Wilantara \& Susilawati (2016) adalah kepercayaan (trust), norma-norma (norms), dan jaringan (network). Parameter inilah yang akan digunakan dalam penelitian ini karena relevan dengan konteks di Kota Manado yang kental dengan budaya Mapalus (menganut nilai-nilai seperti trust, network, norms).

Kepercayaan adalah harapan yang berkembang dalam sebuah masyarakat yang terlihat oleh adanya tindakan yang menunjukkan kejujuran, keteraturan, dan kerjasama berdasarkan norma-norma yang dianut bersama (Wilantara \& Susilawati, 2016). Kepercayaan akan memicu terjadinya energi kolektif sehingga memacu berkembangnya jiwa kewirausahaan dan ide-ide untuk mendapatkan model kerja dengan skala ekonomi yang lebih baik. Pelaku usaha yang mendapat kepercayaan dari masyarakat dapat bertahan di tengah krisis. Alasannya, karena kepercayaan tersebut mendorong pelaku usaha untuk memanfaatkan sumberdaya dan kesempatan untuk melakukan inovasi demi memenuhi permintaan pemangku kepentingannya, seperti pelanggan, lingkungan, dan pemasok. Kepercayaan yang tinggi dari pihak-pihak ini dapat mempertahankan usaha dalam jangka panjang.

Usaha-usaha tradisional yang berdiri sejak zaman dahulu sampai saat ini disebabkan karena adanya interaksi sosial yang baik dengan lingkungan usahanya. Hal ini dibuktikan oleh sikap keterbukaan yang tinggi (agreeableness) dengan lingkungan sehingga menumbuhkan loyaloitas lingkungan terhadapnya. Lebih jauh lagi, dalam jangka panjang lingkungan percaya dan mendukung keberlangsungan usaha ini. Temuan Purnomo \& Lestari (2010) membuktikan bahwa keterbukaan dari pelaku usaha berdampak signifikan terhadap kinerja usahanya. Kepercayaan dari lingkungan tidak tumbuh dalam waktu yang singkat. Karakter ini dibangun dengan jerih juang yang tinggi sehingga nilainya dipandang lebih besar dari nilai uang. Hadiyati (2014) dan Darya (2012) menemukan bahwa karakter dapat dipercaya yang dimiliki oleh pelaku usaha turut meningkatkan kinerja usaha. Bulan \& Muhar (2020) juga menemukan bahwa kepercayaan dari 
lingkungan usaha berkontribusi signifikan terhadap kinerja usaha kecil.

Norma dapat berupa berbagai pemahaman, nilai, harapan, dan tujuan yang diyakini dan dijalankan secara bersama oleh sekelompok orang (Wilantara \& Susilawati, 2016). Norma juga merujuk pada aturan yang berlaku di lingkungan usaha. Kinerja usaha bergantung pada aturan tersebut. Norma atau aturan yang berlaku dapat melemahkan dan menguatkan sebuah usaha (Estrin et al., 2016; Lindvert et al., 2017). Norma di masyarakat termasuk sebagai modal sosial yang mendukung keberhasilan usaha. Norma juga menjadi aspek yang berpotensi aktual dan positif terhadap outcome yang dihasilkan (Nahapiet \& Goshal dalam Lindvert et al., 2017).

Norma atau aturan yang telah disepakati bersama merupakan faktor eskternal yang turut berpengaruh terhadap kinerja usaha. Seperti hasil yang ditemukan oleh Sudiarta et al. (2014) menemukan bahwa faktor ekternal memiliki pengaruh signifikan terhadap kinerja UMKM. Faktor eksternal yang dimaksud adalah hal-hal dari luar usaha, seperti peraturan dari pemerintah. Salah satu peraturan dari pemerintah adalah Pembatasan Aktivitas Berskala Besar (PSBB). Ketaatan pada regulasi ini secara bersama-sama dalam jangka panjang disebut norma. Norma ini turut memengaruhi usaha kecil.

Jaringan adalah suatu infrastruktur dinamis yang mewujudkan konektivitas kerjasama antar manusia (Wilantara \& Susilawati, 2016). Dengan adanya jaringan, maka komunikasi dan interaksi dapat terfasilitasi dengan baik sehingga mendukung tumbuhnya kepercayaan dan memperkuat kerjasama. Kekuatan modal sosial ditunjukkan melalui seberapa berpengaruh jejaring sosial berkembang dalam masyarakat. Jejaring sosial sendiri merupakan struktur sosial yang dibentuk dari individu atau organisasi. Struktur ini dibentuk melalui satu atau lebih jenis relasi yang spesifik seperti nilai, visi, ide, asal daerah atau budaya, keturunan, kesamaan fungsi, dan sejenisnya. Dua hal yang memengaruhi kualitas jejaring sosial, yakni (1) budaya dan perubahan, serta (2) interaksi sosial.

Interaksi sosial sangat memengaruhi kesatuan anggota masyarakat. Perkembangan teknologi informasi yang diikuti dengan perkembangan media sosial dapat berakibat kepada perubahan pola interaksi sosial secara langsung yang mulai beralih menjadi pola virtual (Wilantara \& Susilawati, 2016:124). Hendriyanto (2015) menegaskan bahwa kemampuan pelaku usaha untuk menjalin hubungan dengan pihak-pihak di lingkungan bisnisnya dapat mendorong kinerja usaha secara signifikan. Hal ini senada dengan temuan Analia et al. (2019) serta Fahmi \& Mudiantono (2019) bahwa network (jaringan) memiliki dampak terhadap keunggulan bersaing pelaku usaha. Pandemi COVID-19 mengharuskan pelaku usaha untuk melakukan improvisasi melalui pemanfaatan jaringan yang ada. Keseimbangan antara hubungan (network) dengan teknologi dapat mendorong peningkatan kinerja usaha.

Beberapa penelitian terdahulu mengkaji dampak modal manusia (Sandra \& Purwanto, 2015), modal fisik (Maheswara et al., 2016), modal sosial (Schenkel et al., 2012) terhadap kinerja usaha dalam kondisi normal. Penelitian kali ini berfokus pada variabel modal sosialdi masa krisis akibat pandemi COVID-19. Alasannya, 
dalam masa krisis uang, aset perusahan, dan keterampilan saja tidak cukup bagi ketahanan usaha tanpa adanya hubungan yang solid dengan lingkungan usaha.

Penelitian ini bertujuan mengkaji peranan modal sosial bagi kelangsungan hidup usaha mikro di masa Pandemi COVID-19. Pelaku usaha perempuan di kota Manado memiliki kemampuan untuk menjalin hubungan dengan pelanggan. Hal ini biasanya didasari oleh hubungan pertemanan dan kekeluargaan. Hasil kajian diharapkan memberikan kontribusi bagi pelaku usaha dan pengambil kebijakan untuk semakin memperhatikan pelaku usaha di tengah krisis karena bagaimanapun juga usaha mikro merupakan usaha yang menyerap banyak tenaga kerja, khususnya perempuan. Fokus riset ini secara khusus adalah pelaku usaha perempuan karena perempuan dipandang sebagai pihak yang mampu bertahan dan berkreasi di masa krisis. Fenomena inilah yangterjadi di kota Manado selama masa pandemi.

Berdasarkan penjelasan di atas, maka dirumuskanlah beberapa hipotesis berikut ini:

H1: Kepercayaan berpengaruh positif terhadap kinerja Usaha Mikro

H2: Norma berpengaruh positif terhadap kinerja Usaha Mikro

H3: Jaringan berpengaruh positif terhadap kinerja Usaha Mikro

\section{Metodologi}

\subsection{Jenis dan Sumber Data}

Penelitian ini menggunakan pendekatan kualitatif dan kuantitatif (mixed method) dengan data primer yang bersumber dari observasi, wawancara mendalam (indepth interview), dan penyebaran kuesioner kepada para pelaku usaha mikro di sektor manufaktur di Kecamatan Wenang, Kota Manado. Kuesioner ini dibuat oleh peneliti dengan mengacu pada penelitian sebelumnya dan menyesuaikan dengan kondisi COVID-19. Pendekatan kualitatif dilakukan karena terdapat proses wawancara mendalam yang terjadi antara peneliti dengan pelaku usaha di lapangan. Wawancara dilakukan setelah pengisian kuesioner (quant-qual). Data kuesioner diuji menggunakan Aplikasi SmartPLS M3 3.0.

\subsection{Populasi, Sampel, dan Teknik Pengambilan Sampel}

Jumlah pelaku Usaha Mikro Kecil dan Menengah di Sulawesi Utara adalah 168.000. Populasi dalam penelitian ini adalah para pelaku usaha mikro perempuan yang tersebar di Kota Manado. Pengambilan sampel didasarkan pada teknik convenience sampling dimana pelaku usaha yang ditemui di lapangan langsung dijadikan sebagai sampel. Sampel yang diperoleh adalah 30 pelaku usaha mikro perempuan di Kota Manado. Selama masa pandemi pelaku usaha perempuan mampu bertahan dan berkreasi. Selain itu, pelaku usaha cenderung ditemui di lokasi-lokasi usahanya. 


\subsection{Definisi dan Pengukuran Variabel}

Tabel 2 menggambarkan nama variabel, definisi dan indikator yang diturunkan dari definisi tersebut. Indikator-indikator ini yang akan menjadi ukuran terhadap variabel yang diteliti.

Tabel 2: Definisi Operasional dan Pengukuran Variabel

\begin{tabular}{|c|c|c|}
\hline Variabel & Definisi & Indikator \\
\hline \multirow[t]{2}{*}{$\begin{array}{l}\text { Kepercayaan } \\
\text { (Trust) }\end{array}$} & $\begin{array}{l}\text { Harapan yang berkembang dalam sebuah } \\
\text { masyarakat yang terlihat oleh adanya tin- } \\
\text { dakan yang menunjukkan kejujuran, kete- } \\
\text { raturan, dan kerjasama berdasarkan norma- } \\
\text { norma yang dianut bersama (Wilantara \& } \\
\text { Susilawati, 2016). }\end{array}$ & $\begin{array}{l}\text { - Hubungan langgeng dengan } \\
\text { pelanggan }\end{array}$ \\
\hline & & $\begin{array}{l}\text { - Mengizinkan pelanggan beru- } \\
\text { tang } \\
\text { - Pelanggan menitipkan uang } \\
\text { kembalian } \\
\text { - Berdagang secara rutin } \\
\text { - Pelanggan membeli rutin }\end{array}$ \\
\hline \multirow[t]{2}{*}{ Norma (Norm) } & $\begin{array}{l}\text { Norma adalah berbagai pemahaman, nilai, } \\
\text { harapan, dan tujuan yang diyakini dan di- } \\
\text { jalankan secara bersama oleh sekelompok } \\
\text { orang (Wilantara \& Susilawati, 2016). }\end{array}$ & $\begin{array}{l}\text { - Keluarga (family) mendorong } \\
\text { saya berusaha di masa pandemi. }\end{array}$ \\
\hline & & $\begin{array}{l}\text { - Hubungan baik dengan karya- } \\
\text { wan dan lingkungan } \\
\text { - Mematuhi protokol kesehatan } \\
\text { - Pekerjakan karyawan di masa } \\
\text { COVID-19 }\end{array}$ \\
\hline $\begin{array}{l}\text { Jaringan } \\
\text { (Network) }\end{array}$ & $\begin{array}{l}\text { Infrastruktur dinamis yang mewujudkan } \\
\text { konektivitas kerjasama antarmanusia } \\
\text { (Wilantara \& Susilawati, 2016). }\end{array}$ & $\begin{array}{l}\text { - Menggunakan handphone dan } \\
\text { sosial media untuk menawarkan } \\
\text { produk } \\
\text { - Pangsa pasar di masa COVID- } \\
19 \text { dari segala umur } \\
\text { - Pelanggan adalah orang-orang } \\
\text { yang dikenal sebelumnya } \\
\text { - Lingkungan mempedulikan ke- } \\
\text { langsungan usaha saya }\end{array}$ \\
\hline \multirow[t]{2}{*}{$\begin{array}{l}\text { Kinerja Usaha } \\
\text { (KUM) }\end{array}$} & $\begin{array}{l}\text { Parameter yang menggambarkan hasil ker- } \\
\text { ja yang telah dicapai melalui rangkaian ke- } \\
\text { giatan tertentu pada akhir periode usaha } \\
\text { (Ramaseshan } \text { et al., 2006) }\end{array}$ & $\begin{array}{l}\text { - Peningkatan penjualan selama } \\
\text { COVID-19 }\end{array}$ \\
\hline & & $\begin{array}{l}\text { - Peningkatan modal COVID-19 } \\
\text { - Penambahan pegawai setiap } \\
\text { periode COVID-19 } \\
\text { - Pertumbuhan pangsa pasar se- } \\
\text { lama COVID-19 } \\
\text { - Peningkatan profit (laba bersih) } \\
\text { selama COVID-19 }\end{array}$ \\
\hline
\end{tabular}

Sumber: BPS Sulawesi Utara (2016) 


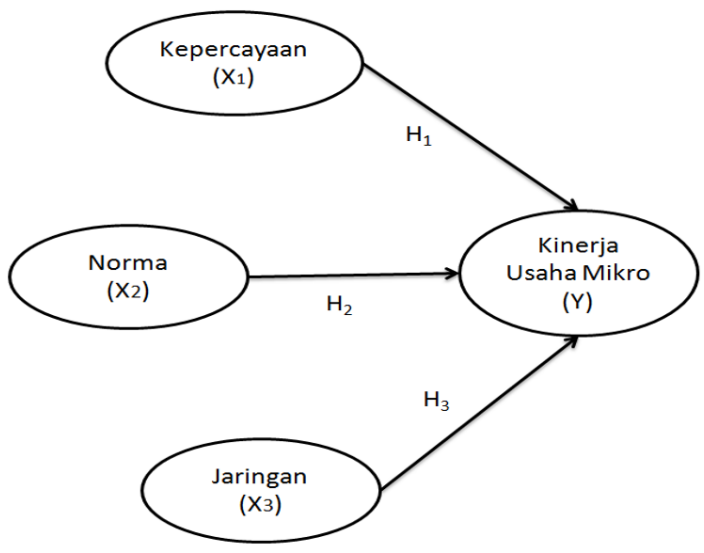

Gambar 1: Kerangka Model Penelitian

\subsection{Teknik Pengujian Hipotesis}

Uji hipotesis yang dilakukan pada model penelitian ini menggunakan Software SmartPLS 3.0M3 yang mensyaratkan jumlah sampel maksimal 100 orang. Proses analisis dilakukan dengan pengujian model secara keseluruhan, melihat kecocokan model pengukuran (uji validitas dan reliabilitas), dan melihat kecocokan model struktural (uji hipotesis). Kemudian untuk mengukur variabel teramati, maka dilihat dari construct validity-nya.

\section{Hasil dan Pembahasan}

\subsection{Demografi Responden}

Karakteristik responden yang diamati dalam kajian ini meliputi pendidikan terakhir, tahun buka usaha, jenis usaha, lama usaha, omzet sebelum dan selama COVID-19. Tabel 3 menampilkan data-data tersebut.

\subsection{Uji Validitas Indikator}

Tabel 4 menunjukkan bahwa semua indikator memenuhi syarat validitas. Hal ini dapat dilihat dari nilai loading factor yang lebih besar dari 0,5. Variabel Trust diwakili oleh 4 indikator, Network dan Norms masing-masing diwakili oleh 3 indikator, serta Kinerja Usaha diwakili oleh 5 indikator.

\subsection{Uji Reliabilitas Indikator}

Dalam pengujian yang menggunakan analisis PLS-SEM yang menggunakan program SmartPLS 2.0 M3, reliabilitas suatu konstruk dengan indikator refleksif 
Tabel 3: Data Demografi Responden

\begin{tabular}{llcc}
\hline \hline Demografi Responden & & Jumlah & Persentase \\
\hline Pendidikan Terakhir & SMP & 1 & $3,33 \%$ \\
& SMA & 9 & $30 \%$ \\
& D-III & 2 & $6,67 \%$ \\
& Sarjana & 18 & $60 \%$ \\
\hline Tahun Buka Usaha & Di bawah tahun 2000 & 3 & $10 \%$ \\
& 2000-2010 & 6 & $20 \%$ \\
& 2010-2020 & 21 & $70 \%$ \\
\hline Jenis Usaha & Jasa & 10 & $33,30 \%$ \\
& Dagang & 13 & $43,30 \%$ \\
& Manufaktur & 7 & $23,30 \%$ \\
\hline Lama Berusaha & < tahun & 14 & $46,67 \%$ \\
& 5-10 tahun & 8 & $26,67 \%$ \\
& $>10$ tahun & 8 & $26,67 \%$ \\
\hline Omzet per Bulan & <Rp10.000.000 & 6 & $20 \%$ \\
& Rp10.000.000-Rp25.000.000,- & 7 & $23 \%$ \\
& $>$ Rp25.000.000-Rp50.000.000,- & 9 & $30 \%$ \\
& $>$ Rp50.000.000 & 8 & $27 \%$ \\
\hline Omzet per Bulan & <Rp10.000.000 & 14 & $47 \%$ \\
(selama COVID-19) & Rp10.000.000-Rp25.000.000,- & 9 & $30 \%$ \\
& $>$ Rp25.000.000-Rp50.000.000,- & 4 & $13 \%$ \\
& $>$ Rp50.000.000 & 3 & $10 \%$ \\
\hline
\end{tabular}

Sumber: Diolah dari data survei

Tabel 4: Uji Validitas Indikator

\begin{tabular}{llcc}
\hline \hline Konstruk & Indikator & Load Factor $>0,50$ & Validitas \\
\hline Trust & Trust1 & 0,541 & Valid \\
& Trust2 & 0,716 & Valid \\
& Trust3 & 0,898 & Valid \\
& Trust5 & 0,782 & Valid \\
\hline Network & Network2 & 0,652 & Valid \\
& Network3 & 0,638 & Valid \\
& Network4 & 0,673 & Valid \\
\hline Norms & Norms2 & 0,699 & Valid \\
& Norms3 & 0,580 & Valid \\
& Norms4 & 0,751 & Valid \\
\hline Kinerja Usaha & Kinerja_Usaha1 & 0,787 & Valid \\
& Kinerja_Usaha2 & 0,737 & Valid \\
& Kinerja_Usaha3 & 0,521 & Valid \\
& Kinerja_Usaha4 & 0,703 & Valid \\
& Kinerja_Usaha5 & 0,824 & Valid \\
\hline
\end{tabular}

Sumber: Data output Software SmartPLS.

diukur dengan melihat nilai composite reliability. Nilai composite reliability harus melebihi dari angka 0,70 (Latan \& Ghozali, 2012). Dari Tabel 5 dapat dilihat bahwa semua variabel menunjukkan nilai composite reliability di atas 0,70 sehingga dinyatakan reliabel. 
Tabel 5: Hasil Uji Reliabilitas

\begin{tabular}{lcc}
\hline \hline Variabel Laten & Composite Reliability $\geq 0,70$ & Kesimpulan \\
\hline Trust & 0,846 & Reliabel \\
Network & 0,83 & Reliabel \\
Norms & 0,719 & Reliabel \\
Kinerja Usaha Mikro & 0,806 & Reliabel \\
\hline Sumber: Data output Software SmartPLS.
\end{tabular}

\subsection{Uji Kecocokan Model Struktural}

Trust menunjukkan pengaruh positif sebesar 0,354 terhadap kinerja usaha mikro yang terlihat dengan nilai t-statistik sebesar 2,292. Sementara, network berpengaruh positif terhadap kinerja usaha mikro yang terlihat dengan nilai t-statistik 2,584 . Norms tidak berpengaruh terhadap kinerja usaha dengan nilai statistik di bawah 1,96 yakni 1,713 .

Tabel 6: Hasil Kecocokan Model Struktural

\begin{tabular}{ccccc}
\hline \hline Hipotesis & Path & Total Effects & T-statistics $\geq 1,96$ & Kesimpulan \\
\hline H1 & Trust $\rightarrow$ Kinerja & 0,354 & 2,292 & Terdukung \\
H2 & Network $\rightarrow$ Kinerja & 0,43 & 2,584 & Terdukung \\
H3 & Norms $\rightarrow$ Kinerja & $-0,425$ & 1,713 & Tidak Terdukung \\
\hline Sumbr:
\end{tabular}

Sumber: Data output Software SmartPLS.

\subsection{Kepercayaan (Trust) dan Kinerja Usaha Mikro}

Kepercayaan (trust) terbukti berpengaruh signifikan sebesar 0,354 terhadap kinerja usaha mikro dengan t-statistik 2,292 > t-tabel 1,96. Hal ini senada dengan temuan Bulan \& Muhar (2020), yang menemukan bahwa terdapat pengaruh signifikan dari interaksi sosial terhadap keberhasilan usaha. Hal ini didukung oleh kepercayaan (trust) sebagai faktor utama bagi kinerja pelaku usaha. Kepercayaan ini diwujudkan dalam bentuk keharmonisan hubungan dengan pelanggan sehingga mengizinkan pelanggan membeli secara kredit (utang), bahkan menitipkan uang pada pelaku usaha, serta membeli secara rutin.

Kepercayaan yang diterima dari pelanggan, keluarga dan lingkungan mendorong pelaku usaha perempuan untuk melakukan improvisasi pada usaha. Hal ini senada dengan temuan Binarto (2013) bahwa kemajuan usaha mikro dipengaruhi oleh dukungan keluarga. Improvisasi yang dilakukan pelaku usaha adalah seperti menawarkan produk (makanan) kepada saudara, teman dan kenalan melalui media sosial maupun handphone, menitipkan produk pada rumah makan yang masih tetap berjualan, menciptakan produk baru sesuai kebutuhan di masa pandemi, mengurangi karyawan, membatasi unit produksi, menurunkan harga produk, dan menyediakan paket promo. Grafik 3 menggambarkan improvisasi tersebut. 
Grafik 2 menunjukkan bahwa pelaku usaha cenderung melakukan improvisasi berupa mempromosikan produk melalui media sosial (22\%) dan menciptakan produk baru sesuai kebutuhan di masa pandemi (18\%). Improvisasi lainnya yang cukup banyak dilakukan adalah meningkatkan layanan kepada pelanggan $(12 \%)$. Beragam improvisasi dilakukan demi mendukung jalannya arus kas usaha. Meskipun pandemi menyebabkan pelanggan menurun drastis, namun masih ada pelanggan yang membeli produk. Hal ini menunjukkan bahwa kepercayaan yang telah diletakkan pada pelaku usaha tidak berubah meskipun dilanda krisis. Hasil riset ini membuktikan secara empiris bahwa kepercayaan yang diperoleh dari pelanggan berpengaruh signifikan terhadap kinerja usaha mikro. Hal ini tampak dari aktivitas produksi yang tetap dilakukan meskipun krisis terjadi.

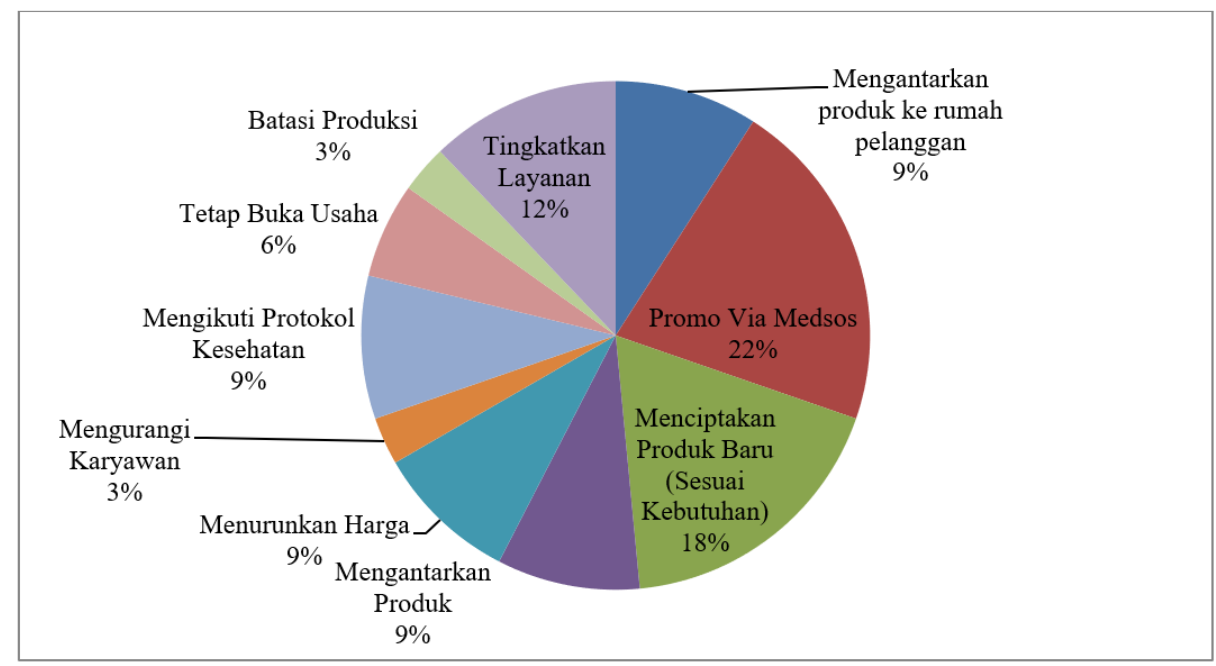

\section{Grafik 2: Improvisasi Pelaku Usaha Mikro di Masa Pandemi COVID-19} Sumber: Diolah dari data survei

Kepercayaan mendorong improvisasi pelaku usaha (Bulan \& Muhar, 2020). Makin baik kepercayaan lingkungan terhadap usaha maka semakin banyak improvisasi yang dilakukan demi mempertahankan usaha di tengah krisis. Lebih jauh lagi, kepercayaan tidak hanya datang dari pelanggan, namun juga dari pemilik usaha. Pemilik usaha yang telah mempercayai karyawannya mengalami kesulitan untuk merumahkan mereka. Kuatnya ikatan kepercayaan yang terbangun antara kedua pihak ini membuat sehingga pemilik usaha tetap memutuskan untuk menjalankan usaha demi menjamin kesejahteraan karyawannya. Hasil wawancara menggambarkan tanggapan seorang pemilik usaha yang tetap mempekerjakan karyawan di masa pandemi:

“Di masa pandemi ini rumah makan rugi karena pelanggan yang datang mengalami penurunan sebanyak $50 \%$. Biasanya pelanggan 
yang datang merupakan para pegawai di sekitar Rumah Makan, namun karena kantorditutup akibat Work Form Home maka penjualan menurun drastis. Di sisi lain, jika kami tidak berjualan, dampaknya adalah pekerja tidak dapat gaji. Mereka akan kesulitan (YR, Usaha Rumah Makan)."

Pernyataan ini menyiratkan bahwa keputusan untuk merumahkan karyawan bukanlah keputusan yang tepat di masa pandemi karena berdampak pada kondisi psikis dan jasmani karyawan. Hal lain yang membuat pelaku usaha tetap berdagang adalah karena pelaku usaha tidak lepas dari kewajiban untuk mencicil pinjaman di bank, meskipun dengan bunga yang telah diturunkan pemerintah. Salah satu hal yang mendukung usaha tetap berjalan adalah relasi dan pelanggan tetapnya.

\subsection{Jaringan (Network)}

Dengan nilai $t$-statistics sebesar 2,584, hasil pengujian membuktikan bahwa Network berpengaruh positif terhadap kinerja usaha mikro. Pangsa pasar di masa pandemi dimulai dari anak-anak sampai orang dewasa. Selain itu, pelanggan yang membeli barang merupakan orang-orang yang berada di lingkungan pelaku usaha sehingga. Hal ini mengindikasikan bahwa lingkungan pelaku usaha mempedulikan kelangsungan usahanya di masa pandemi. Hal ini senada dengan hasil temuan Raymond et al. (2013) bahwa kinerja usaha mikro ditentukan oleh netwok (pengaruh lingkungan usaha). Lerner \& Almor (2002) juga menemukan bahwa kinerja usaha yang dijalankan oleh perempuan cenderung ditentukan oleh cara memasarkan produk kepada lingkungan atau jaringan usahanya. Kozubíková et al. (2020) menemukan faktor sosial seperti lingkungan keluarga turut memengaruhi kualitas usaha.

Pelaku usaha mengandalkan relasi-relasi sosial untuk menjajakan dagangannya. Usaha mengalami kemacetan beberapa hari, namun setelah itu pelaku usaha mulai melakukan improvisasi dengan mengandalkan teman, anggota keluarga, tetangga, dan pelanggan lainnya untuk menawarkan produknya. Pandemi COVID-19 juga telah menyebabkan banyak pekerja dirumahkan. Seorang mahasiswi beralih menjadi pedagang kue di masa krisis ini. Di samping berupaya menyelesaikan tugas akhir untuk meraih gelar sarjana ekonomi, mahasiswi ini juga nekat berkeliling kota menawarkan kue kepada relasi-relasinya. Relasinya diandalkan untuk mempertahankan usahanya. Berikut penjelasan pengalamannya:

"Sebelumnya saya bekerja di Mall namun karena Mall ditutup jadi saya membantu Ibu berjualan kue. Saya biasanya menawarkan kue kepada teman-teman kuliah lewat WhatsApp dan Facebook. Jika mereka memesan, saya langsung mengantar pesanan ke rumah mereka menggunakan sepeda motor. Kami biasanya berkeliling untuk mengantar pesanan. Cara ini cukup membantu jalannya usaha Ibu 
di musim pandemi ini. Dari hasil penjualan, saya bisa mendapatkan uang dari Ibu (LK, Pedagang Kue)"

Hal ini menyiratkan bahwa dirumahkan bukanlah keputusan yang tepat bagi kaum pekerja karena mereka kehilangan penghasilan. Hal tersebut tidak menurunkan daya juang pelaku usaha. Ketika semua penduduk dianjurkan untuk stay at home, pelaku usaha terus berupaya melakukan impovisasi demi mendapatkan penghasilan. Improvisasi seperti mengantarkan produk ke rumah pelanggan adalah upaya menjaga arus kas usaha tetap berjalan, meskipun omzet menurun drastis. Konsumen yang membeli dagangan sebagian besar merupakan relasi pelaku usaha. Hal ini membuktikan bahwa relasi sosial yang telah terbangun sebelumnya dapat diandalkan dalam masa krisis.

Selama masa pandemi COVID-19, ada pelaku usaha yang mengalami penurunan omzet secara signifikan. Masa pandemi turut berdampak pada keputusan pembelian konsumen. Selama masa krisis ini, tingkat pemasukan usaha menurun $50 \%$ karena konsumen tidak membeli produk seperti pada saat kondisi normal. Konsumen lebih mempertimbangkan pengeluarannya. Penurunan omzet ini tidak mengurungkan niat pelaku usaha untuk tetap menjalankan usaha. Berdasarkan hasil wawancara dari salah satu responden mengungkapkan bahwa:

"Di musim COVID-19 ini, orang-orang tetap membeli produk kami. Hanya saja mereka membeli dalam jumlah sedikit, tidak seperti biasanya. Sekarang mereka mengukur pengeluaran mereka. Anak-anak yang jajan juga menurun drastis (DD, Usaha Toko Kelontong)"

“Selama COVID-19, omzet menurus drastis. Dulu, Ibu biasnya mentitip kue di toko dan pasar. Namun karena toko dan pasar ditutup jadi ibu berjualan kue keliling. Itupun tergantung dari pelanggan. Pelanggan berkurang. Saya menawarkan kepada teman-teman lewat FB deng WA (LK, Usaha Kue)"

Hasil wawancara ini menyiratkan bahwa selama COVID-19 melanda, usaha mengalami penurunan omzet, namun pelaku usaha tidak menyerah karena pelaku usaha berusaha menjaga arus kas. Adapula kendala utama yang dialami masa pandemi COVID-19 ini. Sebanyak 77\% responden menjawab kendala utama yang dihadapi adalah menurunnya pelanggan. Hal ini mengakibatkan omzet menurun drastis sehingga usaha melemah. Selanjutnya, sebanyak $10 \%$ responden mengalami penundaan pengiriman produk karena masa PSBB, 7\% responden terkendala karena pembatasa waktu (PSBB), 3\% responden mengaku terkendala karena pelanggan yang gagal membayar jasanya, dan 3\% responden lainnya mengaku terkendala karena lokasi usaha yang jauh (Grafik 3).

Gainau (2019) menyatakan bahwa salah satu kendala untuk mencapai kinerja yang baik adalah resistensi terhadap perubahan. Untuk tetap menghasilkan kinerja yang baik maka seseorang harus menyesuaikan diri dengan perubahan. Ketika virus COVID-19 mewabah, seluruh masyarakat, termasuk pelaku usaha mikro mengalami perubahan kebiasaan. Kebiasaan berdagang di tempat usaha 


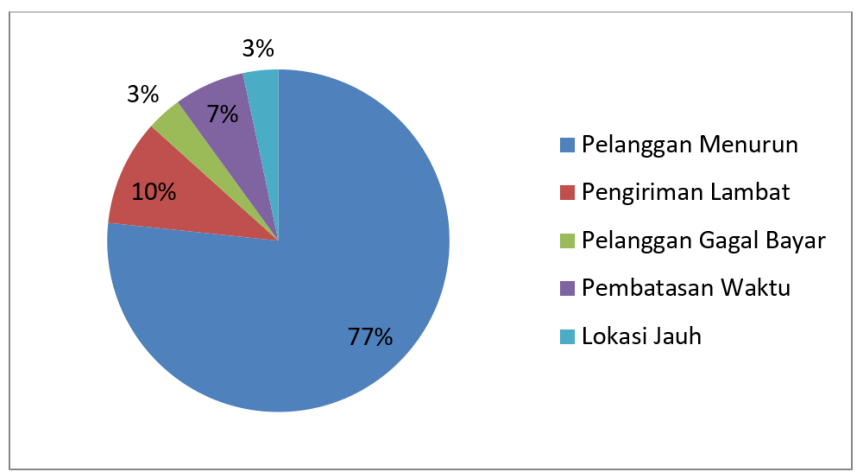

Grafik 3: Kendala Pelaku Usaha di Masa Pandemi

Sumber: Diolah dari data survei

tertentu, kini harus berdagang di media sosial, dan perubahan-perubahan lainnya. Pelaku usaha harus menyesuaikan diri dengan tuntutan COVID-19 agar usaha tidak stagnan.

Kebijakan Pemerintah dalam melaksanakan Pembatasan Sosial Berskala Besar (PSBB) ternyata berdampak bagi pelaku usaha yang membutuhkan jasa penerbangan untuk mengirimkan produk kepada pelanggan. Hal ini menyebabkan sehingga pelaku usaha harus menunggu sampai sebulan untuk dapat mengirimkan produknya. Dampaknya, arus kas menjadi macet, usaha melemah. Lebih jauh lagi, pelaku usaha memutuskan untuk menunda pengirimkan produk sampai masa PSBB berakhir untuk menghindari kerugian yang lebih besar. Hasil wawancara dengan seorang perempuan pelaku usaha mikro menyatakan bahwa:

"Selama masa pandemi, semua kiriman kepada pelanggan tertunda sampai satu bulan akibat pembatasan penerbangan. Akhirnya semua barang dikirim lewat jalur darat dan laut, dan itu memakan waktu yang lama. Di saat seperti itu, saya melakukan penawaran produk melalui media sosial, seperti menawarkan produk (handmade pot cement, reseller gitar lele, dan piyama). Cukup banyak konsumen yang memesan karena harga terjangkau, kualitas baik, dan saya juga jujur ketika menerapkan harga jual. Hanya saja karena kendala pengiriman, saya terpaksa menunda semua orderan sampai bulan Juli. Untuk saat ini saya memilih mengistirahatkan bisnis saya dan akan mulai kembali ketika PSBB sudah tidak dijalankan (ML, Usaha Pot Bunga)"

\subsection{Norma (Norms)}

Hasil pengujian pengaruh norma terhadap kinerja usaha ternyata tidak memiliki pengaruh dengan nilai statistik di bawah 1,96 yakni 1,713. Norma merupakan sesuatu yang berasal dari luar usaha. Norma meliputi aturan-aturan yang ber- 
laku secara umum dan harus dipatuhi oleh pelaku usaha maupun masyarakat di sekitarnya. Hasil uji membuktikan bahwa norma yang berlaku tidak memengaruhi kinerja usaha mikro. Hal ini senada dengan temuan (Kuépié et al. (2016) bahwa hukum atau aturan tidak berpengaruh terhadap keuntungan yang dicapai pelaku usaha. Demikian juga temuan Purwidianti \& Rahayu (2015) bahwa faktor eksternal, seperti aturan, secara signifikan tidak memiliki pengaruh terhadap kinerja usaha. Grafik 4 menunjukkan adanya penurunan omzet, namun tidak menghentikan pelaku usaha untuk berdagang di masa krisis. Dari sisi omzet, pelaku usaha mengalami penurunan karena pelanggan yang berkurang, namun dari sisi operasional, pelaku usaha tetap berdagang. PSBB tidak menghilangkan niat pelaku usaha untuk berdagang di masa krisis.

Pandemi COVID-19 memunculkan kebijakan atau norma baru untuk work from home (WFH). Semua masyarakat harus mematuhinya, termasuk pelaku usaha perempuan. Penerapan kebijakan ini terbukti tidak berpengaruh pada kinerja usaha mikro di masa pandemi. Hal ini dapat dilihat dari meskipun PSBB diberlakukan, pelaku usaha perempuan tetap berupaya berdagang meskipun omzet yang dicapai tidak seperti biasanya. PSBB tidak menghentikan perempuan pelaku usaha dari aksi berjualan. Hal ini senada dengan temuan Gainau (2019) bahwa peraturan dari pemerintah tidak memengaruhi kinerja menjalankan sebuah upaya (program).

Sektor usaha mikro merupakan salah satu industri yang padat tenaga kerja, khususnya pada saat berproduksi dan berjualan. Rantai nilai ini menyediakan lapangan kerja yang umumnya adalah perempuan karena membutuhkan kreasi dan inovasi. Pada umumnya, pedagang perempuan memiliki kemampuan untuk mengekstraksi sumber daya dari jaringan sosial yang di sekelilingnya. Kemampuan tersebut muncul secara alami di dalam diri perempuan. Hal tersebut dapat dilihat saat COVID-19 mulai menjangkiti masyarakat, pedagang tetap berupaya berdagang keliling. Selain harus berupaya berdagang, pedagang perempuan juga menghadapi krisis yang lain,seperti mendapat tekanan dari suami. Berikut ini gambaran kondisi seorang pelaku usaha perempuan yang diungkapkan dalam bahasa lokal Manado:

"Saya berjualan sehari dua kali, pagi dan sore. Meskipun harus bersembunyi dari kejaran Satpol-PP, yang penting saya dapat berjualan. Jika saya tidak berjualan, keluarga kami akan kesulitan untuk makan. Suami saya di rumah, tidak bekerja karena sering sakit. Terkadang ketika saya pulang berjualan, dia mengusir saya karena kuatir saya sudah terkena virus corona akibat berjualan keliling (OL, Pedagang Kue Keliling)"

Pernyataan di atas menyiratkan bahwa PSBB tidak menghentikan pelaku usaha dari aksi berjualan. Hal ini membuktikan bahwa pedagang perempuan memiliki kemampuan berjuang di masa krisis. Kemampuan ini tampak dari ketika pedagang memproduksi produknya dan menjual keliling kota. Upaya ini tentu tidak mudah dilakukan karena harus menghadapi teguran Satuan Polisi Pamong 
Praja (Satpol-PP). Lebih lauh lagi, setelah berdagang, pedagang perempuan harus menghadapi tekanan dari suami yang tidak mendukung usahanya.

Anjuran pemerintah untuk stay at home adalah baik bagi sebagian kelompok masyarakat, namun tidak baik untuk kelompok masyarakat lainnya. Bagi masyarakat yang pekerjaannya dapat diselesaikan dari rumah (misalnya guru, dosen, pegawai kantor swasta, pegawai kantor, dan pemerintah), stay at home adalah anjuran yang tepat. Hal ini menjadi tidak tepat jika diberlakukan bagi para pelaku usaha mikro. Alasannya, karena kebutuhan hidup pelaku usaha setiap hari bersumber dari hasil penjualan sehingga jika tidak berdagang, pelaku usaha tidak dapat memenuhi kebutuhan hidup keluarga.

Penerapan kebijakan PSBB ini menurunkan omzet pedagang sekitar 50\%. Pelaku usaha tetap berdagang, meskipun omzet menurut. Hal ini menunjukkan bahwa PSBB tidak menghilangkan niat pelaku usaha untuk berdagang di masa krisis. Hal tersebut dapat dilihat pada Grafik 4 dan 5.

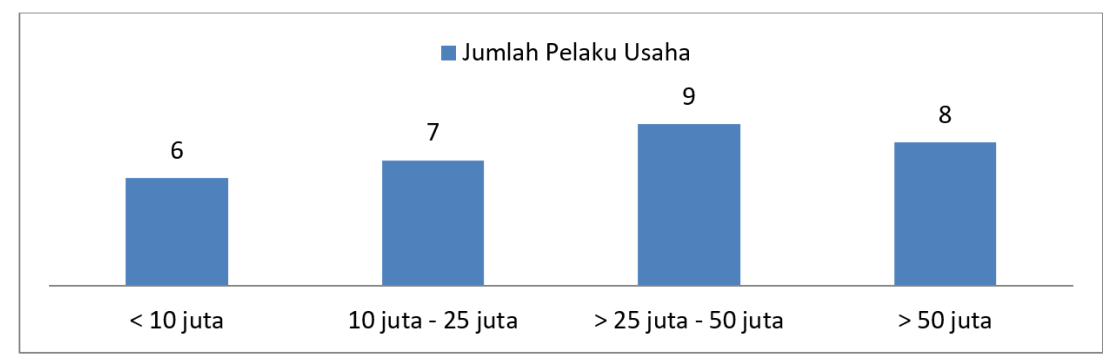

Grafik 4: Jumlah Pelaku Usaha Berdasarkan Kelompok Omzet per Bulan Sebelum Pandemi

Sumber: Diolah dari data survei

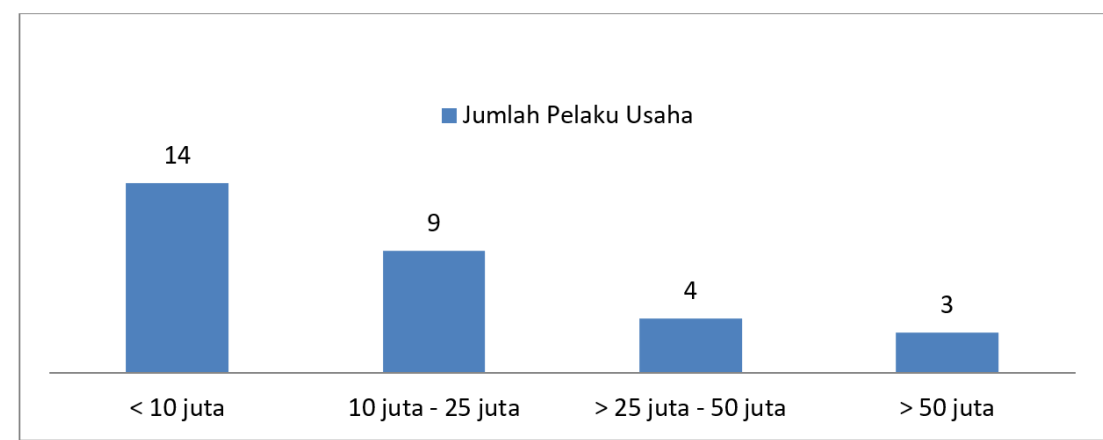

Grafik 5: Jumlah Pelaku Usaha Berdasarkan Kelompok Omzet per Bulan Selama Pandemi

Sumber: Diolah dari data survei 
Sebelum COVID-19 menjangkiti Kota Manado, omzet pelaku usaha berkisar di atas Rp25.000.000, namun selama masa pandemi, omzet pengusaha menurun drastis menjadi kurang dari Rp10.000.000. Penurunan omzet ini disebakan oleh karena menurunnya pelanggan. Kebijakan PSBB membuat masyarakat mengalami ketakutan untuk membeli produk-produk makanan. Krisis di masa pandemi melahirkan daya juang yang lebih besar dari kaum perempuan. Selain karena kepercayaan dan jaringan yang dimiliki, perempuan juga terkenal sebagai sosok yang tahan di dalam tekanan, kreatif dalam setiap keadaan. Turbulensi dalam usaha mikro adalah hal yang wajar, namun improvisasi harus tetap dilakukan agar arus kas usaha tetap berjalan, dan pada akhirnya usaha tetap bertahan di masa krisis.

\section{Kesimpulan}

Berdasarkan analisis data yang teah diakukan maka ada beberapa kesimpulan yang dapat ditarik dari kajian ini, sebagai berikut:

1. Hubungan yang langgeng dengan pelanggan mendorong terbangunnya kepercayaan yang kuat dari pelanggan terhadap usaha. Kepercayaan ini kemudian menjadi faktor utama yang menunjang ketahanan usaha mikro di masa pandemi COVID-19. Kontribusi yang diberikan oleh pelanggan ini harus dibarengi dengan kebijakan dari pemerintah. Kebijakan untuk stay at home belum tepat bagi semua kalangan karena pada umumnya pelaku usaha berdagang untuk memenuhi kebutuhan pokoknya (pangan dan dan mencicil pinjaman).

2. Selama masa pandemi, pelanggan yang berbelanja berasal dari kalangan anak-anak sampai orang dewasa. Kalangan ini juga merupakan keluarga, sahabat dankenalan dari pelaku usaha yang turut mendukung ketahanan usaha di masa krisis. Jaringan (network) berdampak signifikan terhadap kinerja usaha. Jaringan ini mendorong pelaku usaha untuk menciptakan produk baru sesuai kebutuhan di masa pandemi, menggunakan sosial media secara intens untuk mempromosikan produknya, serta mengantarkan produk ke rumah pelanggan.

3. Kinerja usaha mikro tidak secara penuh dibatasi oleh pandemi COVID-19. Hal ini dibuktikan oleh hasil uji variabel norma (norms) yang tidak berpengaruh terhadap kinerja usaha. Pelaku usaha tetap berusaha meskipun dilanda pandemi serta dilemahkan oleh turunnya omzet secara signifikan. Hal mendasar yang dipertimbangkan pelaku usaha adalah agar usaha tetap berjalan, kebutuhan keluarga tercukupi, dan tenaga kerja tetap memiliki penghasilan.

\subsection{Implikasi Terapan}

Pemerintah Kota Manado perlu mempertimbangkan kelangsungan hidup usaha mikro ketika membuat kebijakan di tengah pandemi karena keberadaan usaha mikro menyerap banyak tenaga kerja di Kota Manado. Kebijakan ini dapat berupa penyediaan infrastruktur usaha dan forum kewirausahaan untuk 
memberdayakan pelaku usaha. Infrastruktur dimaksudkan agar pelaku usaha diberdayakan untuk melakukan improvisasi produknya di masa pandemi, sedangkan forum kewirausahaan dimaksudkan untuk pelaku usaha memperluas jaringannya di masa krisis. Makin baik improvisasi produk, makin meningkat juga kepercayaan pelanggan terhadap usaha. Semakin terbuka ruang untuk forum kewirausahaan, semakin luas juga jaringan (networking) pelaku usaha.

\subsection{Implikasi Teoritis}

Secara teoritis, penelitian ini mengkonfirmasi bahwa alasan di balik ketahanan suatu usaha di masa krisis adalah modal sosial. Eksistensi suatu usaha tidak cukup didukung oleh modal fisik dan modal manusia, tetapi juga modal sosial. Modal sosial berkaitan dengan kemampuan pelaku usaha dalam menjalin hubungan yang baik (trust dan network) dengan lingkungan usahanya. Modal sosial sulit dihitung secara kuantitatif dan jarang muncul di dalam catatan keuangan perusahaan namun jenis modal ini berdampak signifikan bagi ketahanan usaha di masa krisis. Untuk itu, pelaku usaha perlu meningkatkan kemampuan untuk menjalin hubungan baik dengan lingkungannya.

\subsection{Keterbatasan Penelitian}

Periode penelitian ini berlangsung di masa pandemi sehingga peneliti mengalami kesulitan ketika mencari responden (responden yang ditemui di lapangan yang dijadikan sampel) sehingga berdampak pada generalisasi hasil penelitian. Penelitian mendatang disarankan untuk memperluas sampel penelitian.

\section{Daftar Pustaka}

[1] Analia, D., Syaukat, Y., Fauzi, A., \& Rustandi, E. (2019). Modal sosial (network) upaya meningkatkan kinerja Usaha Mikro Kecil (UMK) di Kota Padang Sumatera Barat. Jurnal Ekonomi Pertanian dan Agribisnis, 3(1), 108-117. doi: https://doi.org/10.21776/ub.jepa.2019.003.01.11.

[2] Binarto, R. (2013). Analisa modal sosial dan entrepreneurial leadership pengusaha mikro dan kecil di Jawa Timur. Agora, 1(3), 1451-1458.

[3] BPS Provinsi Sulawesi Utara. (2016). Potensi usaha mikro kecil Provinsi Sulawesi Utara. Badan Pusat Statistik Provinsi Sulawesi Utara.

[4] BPS Provinsi Sulawesi Utara. (2018). Potensi usaha mikro kecil Provinsi Sulawesi Utara. Badan Pusat Statistik Provinsi Sulawesi Utara.

[5] Bulan, T. R. N., \& Muhar, A. M. (2020). The social capital impact on the performances small medium enterprises. Journal of Talent Development and Excellence, 12(2s), 15661571.

[6] Darya, I. G. P. (2012). Pengaruh ketidakpastian lingkungan dan karakteristik kewirausahaan terhadap kompetensi usaha dan kinerja usaha mikro kecil di kota Balikpapan. Asian Journal of Innovation and Entrepreneurship, 1(01), 65-78. 
[7] Davidsson, P., \& Honig, B. (2003). The role of social and human capital among nascent entrepreneurs. Journal of Business Venturing, 18(3), 301-331. doi: https://doi.org/10.1016/S0883-9026(02)00097-6.

[8] Estrin, S., Mickiewicz, T., \& Stephan, U. (2016). Human capital in social and commercial entrepreneurship. Journal of Business Venturing, 31(4), 449-467. doi: https://doi.org/10.1016/j.jbusvent.2016.05.003.

[9] Fahmi, A. K. A. F., \& Mudiantono, M. (2019). Analisis pengaruh jaringan, teknologi informasi dan komunikasi, serta inovasi terhadap keunggulan bersaing dan kinerja usaha (Studi pada UMKM di Purwokerto). Diponegoro Journal of Management, 8(3), 74-84.

[10] Florin, J., Lubatkin, M., \& Schulze, W. (2003). A social capital model of high-growth ventures. Academy of Management Journal, 46(3), 374-384. doi: https://doi.org/10.5465/30040630.

[11] Gainau, P. C. (2019). Esensi penyusunan anggaran responsif gender di pemerintah daerah: Bagaimana pemerintah daerah menerapkan anggaran responsif gender?, Yogyakarta: Deepublish.

[12] Grootaert, C. \& Van Bastelaer, T. (2002). Understanding and measuring social capital: A multidisciplinary tool for practitioners. Directions in Development 24465. World Bank. Diakses 21 Juni 2020 dari https:/ / openknowledge.worldbank.org/handle/ 10986/14098.

[13] Hadiyati, E. (2014). Karakteristik kewirausahaan dan perusahaan serta kompetensi kewirausahaan sebagai penentu kinerja usaha kecil menengah (UKM). Journal of Innovation in Business and Economics, 5(2), 117-124. doi: https://doi.org/10.22219/jibe.v5i2.2263.

[14] Hendriyanto, A. (2015). Analisis pengaruh jaringan usaha dan inovasi terhadap kinerja UMKM. Jurnal Ilmu Manajemen dan Akuntansi Terapan (JIMAT), 6(1), 44-49.

[15] Kozubíková, L., Dvorský, J., \& Ključnikov, A. (2020). Social factors' impact on the quality of business environment in the SME segment. Scientific Papers of the University of Pardubice, Series D: Faculty of Economics \& Administration, 28(1), 91-102.

[16] Kuépié, M., Tenikue, M., \& Walther, O. J. (2016). Social networks and small business performance in West African border regions. Oxford Development Studies, 44(2), 202219. doi: https://doi.org/10.1080/13600818.2015.1082540.

[17] Latan, H. \& Ghozali, I. (2012). Partial least squares: Konsep, teknik dan aplikasi SmartPLS 2.0 M3 untuk penelitian empiris. Badan Penerbit Universitas Diponegoro.

[18] Lerner, M., \& Almor, T. (2002). Relationships among strategic capabilities and the performance of women-owned small ventures. Journal of Small Business Management, 40(2), 109-125. doi: 10.1111/1540-627x.00044.

[19] Liao, J., \& Welsch, H. (2005). Roles of social capital in venture creation: Key dimensions and research implications. Journal of Small Business Management, 43(4), 345-362. doi: 10.1111/j.1540-627X.2005.00141.x.

[20] Lindvert, M., Patel, P. C., \& Wincent, J. (2017). Struggling with social capital: Pakistani women micro entrepreneurs' challenges in acquiring resources. Entrepreneurship \& Regional Development, 29(7-8), 759-790. doi: https://doi.org/10.1080/08985626.2017.1349190.

[21] Maheswara, A. A. N. G., Setiawarna, N. J., \& Saskara, I. A. N. (2016). Analisis faktorfaktor yang mempengaruhi pendapatan UKM sektor perdagangan di Kota Denpasar. E-Jurnal Ekonomi dan Bisnis Universitas Udayana, 5(12), 4271-4298.

[22] Munizu, M. (2010). Pengaruh faktor-faktor eksternal dan internal terhadap ki- 
nerja usaha mikro dan kecil (UMK) di Sulawesi Selatan. Jurnal Manajemen dan Kewirausahaan (Journal of Management and Entrepreneurship), 12(1), 33-41. doi: https://doi.org/10.9744/jmk.12.1.pp.\%2033-41.

[23] Pierre, A. T. (2017). Local small business development in two Swedish northern rural areas: A matter of synergy, social capital and trust?. Journal of Rural and Community Development, 12(2-3), 143-167.

[24] Primadona \& Emrizal. (2017). Pengaruh modal sosial terhadap produktivitas petani, Polibisnis, 9(1), 89-97.

[25] Purnomo, R., \& Lestari, S. (2010). Pengaruh kepribadian, self-efficacy, dan locus of control terhadap persepsi kinerja usaha skala kecil dan menengah. Jurnal Bisnis dan Ekonomi, 17(2), 144-160.

[26] Purwidianti, W., \& Rahayu, T. S. M. (2015). Pengaruh faktor internal dan eksternal terhadap kinerja usaha industri kecil dan menengah di Purwokerto Utara. Kinerja, 19(2), 149-159. doi: https://doi.org/10.24002/kinerja.v19i2.541.

[27] Ramaseshan, B., Yip, L. S., \& Pae, J. H. (2006). Power, satisfaction, and relationship commitment in Chinese store-tenant relationship and their impact on performance. Journal of Retailing, 82(1), 63-70. doi: 10.1016/j.jretai.2005.11.004.

[28] Rante, Y. (2010). Pengaruh budaya etnis dan perilaku kewirausahaan terhadap kinerja usaha mikro kecil agribisnis di Provinsi Papua. Jurnal Manajemen dan Kewirausahaan (Journal of Management and Entrepreneurship), 12(2), 133-141. doi: https://doi.org/10.9744/jmk.12.2.pp.\%20133-141.

[29] Raymond, L., Marchand, M., St-Pierre, J., Cadieux, L., \& Labelle, F. (2013). Dimensions of small business performance from the owner-manager's perspective: a reconceptualization and empirical validation. Entrepreneurship $\mathcal{E}$ Regional Development, 25(5-6), 468-499. doi: https://doi.org/10.1080/08985626.2013.782344.

[30] Reio Jr, T. G., \& Ghosh, R. (2009). Antecedents and outcomes of workplace incivility: Implications for human resource development research and practice. Human Resource Development Quarterly, 20(3), 237-264. doi: https://doi.org/10.1002/hrdq.20020.

[31] Sandra, A., \& Purwanto, E. (2015). Pengaruh faktor-faktor eksternal dan internal terhadap kinerja usaha kecil dan menengah di Jakarta. Business Management Journal, 11(1), 97-124. doi: http://dx.doi.org/10.30813/bmj.v11i1.623.

[32] Schenkel, M. T., D'Souza, R. R., \& Matthews, C. H. (2012). Entrepreneurial capital: examining linkages in human and social capital of new ventures. Journal of Developmental Entrepreneurship, 17(02), 1250009. doi: https:/ / doi.org/10.1142/S1084946712500094.

[33] Setyawan, A., Susila, I., \& Anindita, S. (2019). Influence of power asymmetry, commitment and trust on SME retailers' performance. Business: Theory and Practice, 20, 216-223. doi: https://doi.org/10.3846/btp.2019.21.

[34] Singh, R. P., Hills, G. E., Lumpkin, G. T., \& Hybels, R. C. (1999). The entrepreneurial opportunity recognition process: Examining the role of self-perceived alertness and social networks. Academy of Management Proceedings, 1999(1), G1-G6. Academy of Management. doi: https://doi.org/10.5465/apbpp.1999.27600505.

[35] Spekman, R. E., \& Carraway, R. (2006). Making the transition to collaborative buyer-seller relationships: An emerging framework. Industrial Marketing Management, 35(1), 10-19. doi: https:/ / doi.org/10.1016/j.indmarman.2005.07.002.

[36] Stam, W., Arzlanian, S., \& Elfring, T. (2014). Social capital of entrepreneurs and small firm performance: A meta-analysis of contextual and methodological moderators. Journal of Business Venturing, 29(1), 152-173. doi: https://doi.org/10.1016/j.jbusvent.2013.01.002. 
[37] Steiner, B., \& Wang, C. (2016). Social capital, religious affiliation and business performance in Denmark. Academy of Management Proceedings, 2016(1), p. 17753. Academy of Management. doi: https://doi.org/10.5465/ambpp.2016.291.

[38] Sudiarta, I. P. L. E., Kirya, I. K., \& Cipta, W. (2014). Analisis faktor-faktor yang mempengaruhi kinerja Usaha Mikro Kecil dan Menengah (UMKM) di Kabupaten Bangli. Jurnal Manajemen Indonesia, 2(1).

[39] Thobias, E., Tungka, A. K., \& Rogahang, J. J. (2013). Pengaruh modal sosial terhadap perilaku kewirausahaan (suatu studi pada pelaku usaha mikro kecil menengah di Kecamatan Kabaruan Kabupaten Kepulauan Talaud). Acta Diurna Komunikasi, 2(2).

[40] Wilantara, R. F., \& Susilawati. (2016). Strategi dan kebijakan pengembangan UMKM: Upaya meningkatkan daya saing UMKM nasional di era MEA. PT Refika Aditama.

[41] Woodhouse, A. (2006). Social capital and economic development in regional Australia: A case study. Journal of Rural Studies, 22(1), 83-94. doi: https://doi.org/10.1016/j.jrurstud.2005.07.003. 
this page intentionally left blank 